\title{
Protein and the critically ill; do we know what to give?
}

\author{
Mike Stroud \\ Institute of Human Nutrition, University of Southampton, Mailpoint 113, F level, Centre Block, \\ Southampton General Hospital, Tremona Road, Southampton SO16 6YD, UK
}

\begin{abstract}
The National Institute for Health and Clinical Excellence (NICE) has recommended that nutrition support in seriously-ill or injured patients should start at $\leq 50 \%$ of the estimated target energy and protein needs. This recommendation has caused some concern, since taking the NICE approach leads to these sick individuals receiving an initial $\mathrm{N}$ provision of only $\leq 0 \cdot 12 \mathrm{~g} \mathrm{~N} / \mathrm{kg}$ per $\mathrm{d}$, as opposed to levels of approximately $0 \cdot 25 \mathrm{~g} \mathrm{~N} / \mathrm{kg}$ per d that have been widely recommended by other expert groups. The basis of the recommendation for higher levels of $\mathrm{N}$ provision is that feeding at levels of $\geq 0.25 \mathrm{~g} \mathrm{~N} / \mathrm{kg}$ per $\mathrm{d}$ reduces the inevitable net $\mathrm{N}$ loss of catabolism and hence minimises overall lean tissue wasting. However, although it has always been assumed that better $\mathrm{N}$ balance must equate with better outcome, there are teleological arguments that question the wisdom of providing more $\mathrm{N}$ to sicker patients and studies that imply that best $\mathrm{N}$ balance might not equate with best clinical progress. Furthermore, current evidence suggests that in most critical illness low initial intakes of both energy and $\mathrm{N}$ lead to improved survival. It therefore seems logical to aim, in the first instance, to feed the seriously ill at only modest levels. Further research is required to determine whether lowerenergy higher- $\mathrm{N}$ feeding would prove better or worse than this approach in terms of clinical benefit rather than just better $\mathrm{N}$ retention. Investigations to explore the use of feeds that are specifically designed to match the amino acid needs of illness are also required.
\end{abstract}

\section{Critical illness: Protein requirements}

The National Institute for Health and Clinical Excellence (2006) has published guidelines on nutrition support in adults. The author, as chairman of the group that produced those guidelines, was not only involved in responding to the extensive comments on two earlier drafts but, since their publication, has discussed them widely. The author is therefore aware that although generally well received, the recommendation, 'Nutrition support should be cautiously introduced in seriously ill or injured people, starting enteral tube feeding or parenteral nutrition at no more than $50 \%$ of the estimated target energy and protein needs', has met with considerable adverse comment.

For some who have voiced criticism the fear is that if the National Institute for Health and Clinical Excellence (2006) recommendations are followed patients would receive an inadequate supply of both energy and $\mathrm{N}$, but for the majority it is primarily fears about inadequate $\mathrm{N}$ that has caused concern. The National Institute for Health and Clinical Excellence (2006) approach leads to seriously-ill individuals receiving an initial provision of $0.12 \mathrm{~g} \mathrm{~N} / \mathrm{kg}$ per $\mathrm{d}$, a level close to the minimum maintenance needs for individuals who are not ill (Institute of Medicine, Food and Nutrition Board, 2005). This level is much lower than the recent recommendations from the European Society for Parenteral and Enteral Nutrition (2006) and the American Society for Parenteral and Enteral Nutrition (2002), which suggest provision of $\geq 0.25 \mathrm{~g} \mathrm{~N} / \mathrm{kg}$ per $\mathrm{d}$. While the concept of supplying only modest amounts of energy during the early phase of serious illness appears to have gained ground amongst experts in clinical nutrition (Elia, 1995), most experts clearly believe that the supply of $\mathrm{N}$ should be generous (Hoffer, 2003). The present paper examines the origins of that belief and questions its validity.

\section{Catabolism, teleology and illness}

There is no doubt that serious illness or injury leads to very high net $\mathrm{N}$ losses. These losses are predominantly a result of the catabolic response, although in many cases there are 
also contributions from impaired intake and absorption of nutrients and/or excess $\mathrm{N}$ losses via the gastrointestinal tract, open wounds, burns etc. Catabolism entails both an increase in protein synthesis and an even greater increase in protein breakdown. It is often thought of as being largely detrimental, but when looking at biology from a teleological viewpoint (according to The Concise Oxford Dictionary (Thompson, 1996) teleology is 'the explanation of phenomena by the purpose they serve rather than by postulated causes'), it must in reality confer some survival advantage in the majority of circumstances. The only way that the operation of such an advantage can be envisaged is that the net tissue breakdown supplies the body with substrates needed to support the very-high nutrient demands of the acute-phase response, immunological defences and wound or tissue recovery.

Why, however, should anorexia and limitation of food intake accompany the catabolic response, when it would seem more logical that with the raised nutrient demands of sickness evolution would have ensured an increased appetite? There are several possible answers to this apparent paradox, including the possibility that lack of appetite limits the drive to move or forage, which might be dangerous when ill or injured. However, the most likely explanation would seem to be that the substrate requirements in the face of catabolism are not only larger than usual but different. If this explanation is valid, the link between catabolism and anorexia might be a means to ensure that the release of substrates specifically needed to cope with the illness or injury is coupled with a mechanism to limit intake of the substrates not currently required. By far the most likely candidates for such specific alterations in substrate requirements are the amino acids (AA) and there is evidence to suggest that such changes do occur.

Reeds et al. (1994) have pointed out that the acute-phase proteins (APC) have a relatively high content of phenylalanine, tryptophan and tyrosine compared with that seen in either transport proteins or muscle or the normal diet. For example, APC contain $105 \mathrm{~g}$ phenylalanine $/ \mathrm{kg}$ whereas muscle protein contains only $40 \mathrm{~g} / \mathrm{kg}$. This disparity means that during the acute-phase response $>2.5 \mathrm{~g}$ endogenous muscle protein (or protein derived from the diet or from conventional nutrition support) is needed to produce $1 \mathrm{~g}$ APC. These authors then went on to measure typical production rates of APC in patients undergoing uncomplicated surgical trauma. They have demonstrated that this imbalance in the AA content of endogenous or exogenous $\mathrm{N}$ sources compared with that of the APC could account for the entire net $\mathrm{N}$ loss seen in such patients, which amounts to about $0.13 \mathrm{~g} \mathrm{~N} / \mathrm{kg}$ per d. Similar arguments can be made for unbalanced demands for other AA, including the Scontaining group and glutamine (Reeds, 2000; Grimble, 2001).

In addition to providing an explanation for much of the observed $\mathrm{N}$ losses seen during catabolism, the unusual pattern of AA demands during more severe illness could explain the teleological purpose of anorexia. As mentioned earlier, the AA pattern provided within the diet essentially matches that needed for the synthesis of 'normal' transport and structural proteins. During illness or injury food intake would therefore provide not only the AA needed for manufacture of APC, but a relative excess of those not required under such circumstances. This excess might be thought of as harmless, and certainly some authorities have suggested that AA toxicity is rare (Soeters et al. 2004). However, animal studies of unbalanced AA feeding show that excess free AA are harmful (Harper \& Peters, 1983), and the anorexia seen in human subjects on high-protein diets also suggests that too many free AA are biologically unwelcome (Weigle et al. 2005). Furthermore, there are complex interactions between AA levels and requirements. For example, three to four molecules of glycine would be required to metabolise one molecule of 'unwanted' methionine, and this requirement could be important if any excess of methionine precipitates relative glycine deficiency, since glycine is needed to maintain antioxidant defences (Meakins et al. 1998).

The potential danger posed by free AA means that the body must either metabolise them or incorporate them into proteins etc. Most can be oxidised to urea, which is usually relatively harmless, but seriously-ill individuals often have renal failure. Furthermore, even if they are not uraemic they are often prone to oedema, and a high production of urea reduces the capacity to excrete salt and water because of the additional glomerular solute load. Of even more concern is the possibility that the capacity of the urea pathway to oxidise any excess AA that are not needed for the acute-phase response might be exceeded if high levels are coming from food or nutrition support as well as from catabolic breakdown. If that situation does occur, the excess 'unwanted' AA would have to be incorporated into peptides and proteins and, since they are of the wrong pattern for the acute-phase response, protein synthesis would need to be pushed back towards 'normal' pathways. This process would improve overall $\mathrm{N}$ balance, but only by forcing metabolism away from pathways chosen by evolution to maximise survival. Furthermore, although there has been a long tradition of ignoring the contribution of protein metabolism to the energy delivery of nutrition support, it must be borne in mind that a patient in net negative $\mathrm{N}$ balance not only receives the energy equivalent of $100 \%$ of any protein given in diet or feeds, but also receives the energy equivalent of most of the net $\mathrm{N}$ loss. High-protein feeding will therefore add to any problems associated with high glucose or lipid provision.

There is one additional interesting conjecture when taking an evolutionary view of catabolism and AA supply. It is widely assumed that the 'essential' AA must be the most important, since they are the AA that are simply indispensable to the body. Teleological thinking turns this reasoning upside down. There are numerous examples amongst the mammals of animals that can produce every $\mathrm{AA}$, and it therefore seems most likely that human ancestors lost the capacity to make those that are now essential in the diet. If true, those for which man has retained the capacity for synthesis (so that supply is maintained even when eating little) must really be the most important during periods of illness and catabolism. Indeed, catabolism could even be a mechanism to limit supplies of the socalled essential AA, whilst maximising the supplies of substrates truly needed for severe illness, which according to Reeds (2000) might be glutamine, arginine and aspartate 
Table 1. Studies on nitrogen balance in different groups of critically-ill patients

\begin{tabular}{|c|c|c|c|}
\hline Study & Patient group & $\begin{array}{l}\text { Levels of } \mathrm{N} \text { provision } \\
(\mathrm{g} / \mathrm{kg} \text { per } \mathrm{d})\end{array}$ & Finding \\
\hline Wolfe et al. (1983) & Burns & 0.35 v. 0.22 & Higher $\mathrm{N}$ provision is of no benefit \\
\hline Shaw et al. (1987) & Sepsis & $0.18,0.24$ and 0.36 & $\begin{array}{l}\text { No change in protein breakdown } \\
\text { Optimal } \mathrm{N} \text { balance } 0.24 \mathrm{~g} \mathrm{~N} / \mathrm{kg} \text { per d }\end{array}$ \\
\hline Larsson et al. (1990) & Severe trauma & $\begin{array}{l}\text { From } 0 \text { to } 0.3 \text { in five } \\
\text { increments }\end{array}$ & $\begin{array}{l}\text { Improved } \mathrm{N} \text { balance at } \leq 0.2 \mathrm{~g} \mathrm{~N} / \mathrm{kg} \text { per } \mathrm{d} \text {, } \\
\text { then no additional benefit }\end{array}$ \\
\hline Ishibashi et al. (1998) & Trauma and sepsis & $0.1,0.24$ and 0.3 & Better $\mathrm{N}$ balance at $0.24 \mathrm{~g} \mathrm{~N} / \mathrm{kg}$ per $\mathrm{d}$ than at $0.3 \mathrm{~g} \mathrm{~N} / \mathrm{kg}$ per $\mathrm{d}$ \\
\hline
\end{tabular}

for lymphocyte proliferation and cysteine, glutamine and glycine for glutathione synthesis.

\section{Nitrogen requirements in serious illness}

The arguments described earlier lead to the conclusion that higher levels of exogenous protein provision might adversely affect seriously-ill individuals. This inference is clearly the opposite of currently-accepted practice, and it would certainly be unreasonable to challenge it on entirely hypothetical grounds. However, when the literature on the $\mathrm{N}$ requirements of the seriously ill is reviewed with such arguments in mind, it is easy to find evidence that appears to support a low-N approach.

The $\mathrm{N}$ requirements of serious illness have been the subject of research over many decades, but nearly all the studies have been small and have used $\mathrm{N}$ balance or preservation of lean tissue mass as the primary end point. In healthy individuals a protein intake equivalent to about $0 \cdot 12 \mathrm{~g} \mathrm{~N} / \mathrm{kg}$ per $\mathrm{d}$ is more than adequate to maintain $\mathrm{N}$ balance (Institute of Medicine, Food and Nutrition Board, 2005), and much lower levels will do so after a period of adaptation, but in illness these levels change dramatically. Studies in the critically ill show that provision at normal maintenance levels is associated with a marked negative $\mathrm{N}$ balance and that levels of approximately $0.25 \mathrm{~g} \mathrm{~N} / \mathrm{kg}$ per $\mathrm{d}$ are needed to minimise net losses (Shaw et al. 1987; Larsson et al. 1990; Ishibashi et al. 1998). Nevertheless, the same studies and others, such as those by Wolfe et al. (1983), show that patients are still in net negative balance and that higher provision still does not help (Table 1).

Since most experts assume that the maintenance of bestpossible $\mathrm{N}$ balance in seriously-ill patients must be associated with better maintenance of organ function, wound healing and immune defence, the data from studies such as those in Table 1 have been used to underpin the common recommendation that the seriously ill or injured should receive $\geq 0 \cdot 25 \mathrm{~g} \mathrm{~N} / \mathrm{kg}$ per d. However, Koretz (2005) has forcefully pointed out the dangers of assuming that studies on intermediate end points cannot be substituted for studies on clinical outcomes, and the teleological arguments presented earlier also suggest that best $\mathrm{N}$ balance may not equate with best clinical outcome. Forcing $\mathrm{N}$ accretion in the face of the catabolic process may compromise evolutionary survival responses, and some animal experiments appear to support this notion. For example, Peck et al. (1989) have shown that high levels of protein provision in a guinea-pig model of peritonitis lead to increased mortality, even though $\mathrm{N}$ retention was found to be best in
Table 2. Mortality in a guinea-pig model of peritonitis with differing levels of nitrogen provision (Peck et al. 1989)

\begin{tabular}{lc}
\hline $\begin{array}{l}\text { Protein in } \\
\text { feed }(\mathrm{g} / \mathrm{kg})\end{array}$ & $\begin{array}{c}\text { Mortality at } \\
14 \mathrm{~d}(\%)\end{array}$ \\
\hline 50 & 59 \\
100 & 77 \\
150 & 88 \\
200 & 85 \\
\hline
\end{tabular}

the groups fed more protein (Table 2). Furthermore, it is now well recognised that the improvement in $\mathrm{N}$ balance that is achieved in critically-ill patients by using growth hormone is associated with significantly higher mortality (39\% deaths in patients receiving the hormone v. 20\% in controls (relative risk 1.9 (95\% CI 1.3, 2.9); $P<0.001$ ); Ruokonen \& Takala, 2000).

\section{Clinical-outcome studies}

If maintenance of best $\mathrm{N}$ balance cannot be used as a surrogate for best practice, analysis of clinical-outcome studies is needed. As in all areas of nutrition support, however, results are difficult to interpret for several reasons, including:

1. optimal levels and balance of nutrition must vary between different groups of patients (e.g. post surgery and those with sepsis, trauma, crush injury, head injury and burns), as well as varying within groups depending on pre-existing malnourishment and the seriousness of the insult;

2. optimal levels and balance of nutrition probably vary within individual patients depending on the timing of planned support in relation to the onset of the problem and stage of its resolution;

3. results from studies are often confused by nonachievement of planned feeding levels, especially in the critically ill if limited gastrointestinal function reduces the effectiveness of any enteral feeding (a problem that invalidates nearly all comparisons of enteral tube feeding $v$. intravenous nutrition in the critically ill);

4. benefits of nutrition support may not always be related to the provision of macronutrients per se, but to mechanisms such as correction of micronutrient deficits, stimulation of cell metabolism or preservation of gut integrity; 
5. in most studies of sick individuals deliberately or inadvertently being given low levels of $\mathrm{N}$, those who receive low levels often receive different levels of energy.

It should also be recognised that in most patients receiving critical care it is highly unlikely that optimising nutrition will have more than modest effects on final outcomes, and hence very large studies would be needed to show benefit. The converse, however, that too much nutrition support could actually be detrimental, could be demonstrated in smaller studies.

Having acknowledged these difficulties, there is also the problem that, as far as the author is aware, there actually have been no studies on the deliberate provision of low-N feeds to any groups of patients in hospital settings. However, some studies undertaken in the context of severe malnourishment in the field may have relevance. In investigations performed in relief camps in Somalia during the famine of 1992-3 (Collins et al. 1998) 573 severelymalnourished adults (mean body weight $35 \mathrm{~kg}$, BMI $13 \cdot 1 \mathrm{~kg} / \mathrm{m}^{2}$ ) were identified, of whom eighty-three were oedematous and 377 non-oedematous. These famine victims were allocated to either high $(16.4 \%)$-protein or low (8.5\%)-protein refeeding regimens. Overall mortality rates were reported to be $21 \%$, but in the oedematous patients they were found to be much higher $(37 \%)$, with striking differences between those receiving low-protein $v$. highprotein feeds (Table 3). The high-protein feeds were also shown to be associated with increasing oedema, whilst low-protein feeds led to oedema resolution.

In explanation, it has been pointed out that the highprotein regimen was also higher in carbohydrate than the low-protein regimen, and hence the differences in outcome may have been ascribable to well-recognised carbohydratetriggered refeeding-type problems. However, persistently poor appetite was observed in the group offered the highprotein feeds as opposed to rapidly-improving appetites seen in the low-protein group. As a consequence, the actual intakes of carbohydrate were probably similar in both groups. The study therefore suggests that high levels of $\mathrm{N}$ provision do increase mortality, possibly by the promotion of continued salt and water retention. Similar findings have also been reported in malnourished children (Golden, 1982; Bredow \& Jackson, 1994).

Although, as already mentioned, there are no low-Nclinical-outcome studies in seriously-ill hospitalised patients, other studies on general levels of feeding can also provide clues. It is now accepted that very high levels of nutrition support, hyperalimentation, are definitely harmful (Cerra, 1987; Elia, 1995) and, although it is easy to ascribe all harm to the high levels of fat or carbohydrate given, it

Table 3. Mortality and oedema in Somalian famine victims given high- and low-protein diets (Collins et al. 1998)

\begin{tabular}{lll}
\hline & $\begin{array}{c}\text { Low protein } \\
(8.5 \mathrm{~g} / \mathrm{kg})\end{array}$ & $\begin{array}{c}\text { High protein } \\
(16.4 \mathrm{~g} / \mathrm{kg})\end{array}$ \\
\hline Mortality & $14 / 52(27 \%)$ & $\begin{array}{c}14 / 27(52 \%) \\
+6.3\end{array}$ \\
\hline
\end{tabular}

is not known whether the high levels of $\mathrm{N}$ also contribute. It is known, however, that the small studies examining $\mathrm{N}$ balance with variable levels of provision (e.g. those shown in Table 1) have not shown clinical benefit when $\mathrm{N}$ losses are minimised, but neither do they suggest obvious harm with higher $\mathrm{N}$ provision. Nevertheless, some retrospective studies of general levels of feeding in patients receiving intensive care suggest that until it has been established that lower-energy higher-N provision really does make a clinical difference, low levels of both might be optimal.

For example, Krishnan et al. (2003) undertook a retrospective analysis of outcomes $v$. achieved feeding levels in 187 patients in the intensive care unit who had not undergone surgery and showed that, overall, patients receiving between one-third and two-thirds of their estimated needs had the best levels of survival compared with those receiving less than one-third or more than two-thirds of their estimated needs (Table 4). These results might be explained by inequalities in the severity of illness represented by patients in each group, since sicker patients would have poorer gastrointestinal function and so would achieve lower levels of feeding, except for the very sickest patients whose gastrointestinal function would be so poor that they would need intravenous nutrition. However, this interpretation cannot explain why among the sicker patients with higher acute physiology scores the group receiving less than one-third of their estimated nutrient needs have the best survival, the group receiving between one-third and two-thirds of their estimated nutrient needs have poorer outcomes and the group receiving more than two-thirds of their estimated nutrient needs have the worst outcomes (Table 4). These results suggest that least is best for the really ill.

Similar results, also favouring very low levels of feeding, have been reported in a randomised controlled trial by Ibrahim et al. (2002) that examined clinical outcomes in patients who were mechanically ventilated and received early $v$. late enteral feeding (Table 5). Although other commentators (Powell-Tuck, 2007; Taylor, 2007) seem happy to ascribe such observations to the benefits of a low-energy approach, while still stating confidently that higher $\mathrm{N}$ must be given, it may be argued that the studies actually support the National Institute for Health and Clinical Excellence (2006) low-energy and low-N approach.

Table 4. Chances of survival in patients fed $33-65$ or $>65 \%$ of their estimated nutritional needs compared with those receiving $<33 \%$ of their needs for 187 patients in the intensive care unit who had not undergone surgery and had differing acute physiology scores (SAPSII; Krishnan et al. 2003)

\begin{tabular}{|c|c|c|c|c|c|}
\hline \multirow{2}{*}{$\begin{array}{l}\text { Energy intake } \\
\text { (\% estimated } \\
\text { need)........ } \\
\text { Patient group }\end{array}$} & \multirow{2}{*}{$\frac{0-32(n 49)}{R R}$} & \multicolumn{2}{|c|}{ 33-65 (n 88) } & \multicolumn{2}{|c|}{$>65(n 50)$} \\
\hline & & $\mathrm{RR}$ & $95 \% \mathrm{Cl}$ & $\mathrm{RR}$ & $95 \% \mathrm{Cl}$ \\
\hline All patients & 1 & $1 \cdot 22$ & $1 \cdot 15,1 \cdot 29$ & $0 \cdot 82$ & $0.87,0.94$ \\
\hline SAPSII $<50$ & 1 & $1 \cdot 67$ & $0.92,2.95$ & 0.98 & $0.61,1.56$ \\
\hline SAPS II> 50 & 1 & 0.83 & $0.77,0.90$ & 0.46 & $0.28,0.75$ \\
\hline
\end{tabular}

$\mathrm{RR}$, relative risk. 
Table 5. Clinical outcomes in patients who were mechanically ventilated and received either 27 or $7.5 \%$ of their needs over the first $4 \mathrm{~d}$ (Ibrahim et al. 2002)

\begin{tabular}{lccc}
\hline & $\begin{array}{c}\text { Low }(n \text { 75), } \\
20 \% \text { estimated } \\
\text { needs for } \\
\text { days 1-4 }\end{array}$ & $\begin{array}{c}\text { Statistical } \\
\text { significance of } \\
\text { difference } \\
\text { between } \\
\text { groups }(P>)\end{array}$ \\
\hline Intake (\% needs) & 27 & 7.5 & 0.0043 \\
Pneumonia (\%) & 49 & 31 & 0.043 \\
ICU stay (d) & 13.6 & 9.8 & 0.02 \\
Hospital stay (d) & 22.9 & 16.7 & \\
\hline
\end{tabular}

ICU, intensive care unit.

Some of the critics of the 'start at 50\%' approach from the National Institute for Health and Clinical Excellence (2006) have cited studies of the benefits of early enteral feeding in intensive care as evidence that the recommendation must be wrong. However, although Heyland et al. (2003) have shown possible benefits in mortality and complications when initiating early enteral feeding in patients receiving intensive care, as did Taylor et al. (1999) for head injury and Lewis et al. (2001) after general surgery, the benefits of such early nutritional intervention almost certainly have no relevance to levels of $\mathrm{N}$ provision. There are many reasons why early enteral intake might grant benefit that has nothing to do with levels of macronutrient provision. Furthermore, it was pointed out many years ago by Jeejeebhoy (1988) that across all feeding settings the 'benefits of nutritional support are evident when too little nutrition is given for too short a time to have any noticeable influence on lean body mass or circulating proteins'. In addition, in most studies of early enteral feeding in the seriously ill or injured the levels of nutrition actually achieved in the first $48 \mathrm{~h}$ are $<50 \%$ of the estimated needs (McClave et al. 1999; Marik \& Zaloga, 2001). Hence, they are closer to the levels recommended by the National Institute for Health and Clinical Excellence (2006) than to any recommendations suggesting higher levels of $\mathrm{N}$. Indeed, the reason why early enteral feeding may be of benefit in the seriously ill may actually be because the levels of feeding achieved are usually limited.

Finally, even if the National Institute for Health and Clinical Excellence (2006) recommendation to introduce feeding at a maximum of $50 \%$ of the estimated needs is followed for 1 week (the National Institute for Health and Clinical Excellence (2006) actually recommends building up to meet full target levels in approximately $48 \mathrm{~h}$, depending on metabolic and gastrointestinal tolerance), a $70 \mathrm{~kg}$ seriously-ill patient given $0 \cdot 12 \mathrm{~g} \mathrm{~N} / \mathrm{kg}$ per $\mathrm{d}$ would receive a total of about $60 \mathrm{~g} \mathrm{~N}$, compared with $120 \mathrm{~g} \mathrm{~N}$ in the same period if given $0 \cdot 25 \mathrm{~g} \mathrm{~N} / \mathrm{kg}$ per $\mathrm{d}$. While at first sight this disparity might appear to be important, the difference of $60 \mathrm{~g} \mathrm{~N}$ must be compared with the total catabolic $\mathrm{N}$ turnover in such a patient over 1 week, which is likely to equate to $>1500 \mathrm{~g} \mathrm{~N}$, with a total negative $\mathrm{N}$ balance of approximately $320 \mathrm{~g}$. It is therefore difficult to conceive of a mechanism whereby, within this context, the higher input might really grant clinical benefit.

\section{Conclusions}

The answer to the question, protein and the critically ill: do we know what to give is an emphatic no. Although there is little doubt that high $\mathrm{N}$ intakes reduce net $\mathrm{N}$ losses in this context, there are no studies to suggest that this approach grants any clinical benefits and several considerations that raise the suspicion that it might do harm. Certainly, current evidence strongly suggests best survival occurs in critically-ill patients who are given small amounts of both energy and $\mathrm{N}$, started as soon as possible, using the enteral route rather than the parenteral route. Further research is required to determine whether modest-energy higher-N feeding would prove better or worse than this approach in terms of clinical benefit and not just $\mathrm{N}$ retention. Investigations to explore the use of feeds that are better designed to match the AA needs of illness are also required.

\section{References}

American Society for Parenteral and Enteral Nutrition (2002) Standards of Practice and Clinical Guidelines for Nutritional Support. Dubrique, IA: Kendall Hunt Publishing Company.

Bredow M \& Jackson A (1994) Community based, effective, low cost approach to the treatment of malnutrition in rural Jamaica. Archives of Disease in Childhood 71, 297-303.

Cerra F (1987) Hypermetabolism, organ failure, and metabolic support. Surgery 101, 1-14.

Collins S, Myatt M \& Golden B (1998) Dietary requirements of severe malnutrition in adults. American Journal of Clinical Nutrition 68, 193-199.

Elia M (1995) Changing concepts of nutrient requirements in disease: implications for artificial nutrition support. Lancet 345, 1279-1284.

European Society for Parenteral and Enteral Nutrition (2006) Guidelines on enteral nutrition: intensive care. Clinical Nutrition 25, 210-223.

Golden M (1982) Protein deficiency, energy deficiency and the oedema of malnutrition. Lancet i, 1261-1265.

Grimble RF (2001) Stress proteins in disease: metabolism on a knife edge. Clinical Nutrition 20, 469-476.

Harper AE \& Peters JC (1983) Amino acid signals and food intake and preference: relation to body protein metabolism. Experientia 44, Suppl., 107-134.

Heyland D, Dhaliwal R, Drover J, Gramlich L \& Dodek P (2003) Canadian clinical practice guidelines for nutrition support in mechanically ventilated, critically ill adult patients. Journal of Parenteral and Enteral Nutrition 27, 355-373.

Hoffer LJ (2003) Protein and energy provision in critical illness. American Journal of Clinical Nutrition 78, 906-911.

Ibrahim E, Mehringer L, Prentice D, Sherman G, Schaiff R, Fraser V \& Kollef M (2002) Early versus late enteral feeding of mechanically ventilated patients: results of a clinical trial. Journal of Parenteral and Enteral Nutrition 26, 174-181.

Institute of Medicine, Food and Nutrition Board (2005) Dietary Reference Intakes: Energy, Carbohydrate, Fiber, Fat, Fatty Acids, Cholesterol, Protein and Amino Acids. Washington DC: National Academy Press.

Ishibashi N, Plank L, Sando K \& Hill G (1998) Optimal protein requirements during the first 2 weeks after the onset of critical illness. Critical Care Medicine 26, 1529-1535.

Jeejeebhoy KN (1988) Bulk or bounce - the object of nutritional support. Journal of Parenteral and Enteral Nutrition 12, 539546. 
Koretz RL (2005) Death, morbidity and economics are the only end-points for trials. Proceedings of the Nutrition Society 64, 277-284.

Krishnan J, Parce P, Martinez A, Diette GB \& Brower RG (2003) Caloric intake in medical ICU patients: consistency of care with guidelines and relationship to clinical outcomes. Chest 124, 297-305.

Larsson J, Lennmarken C, Martensson J, Sandstedt S \& Vinnars E (1990) Nitrogen requirements in severely injured patients. British Journal of Surgery 77, 413-416.

Lewis SJ, Egger M, Sylvester PA \& Thomas S (2001) Early enteral feeding versus nil by mouth after gastrointestinal surgery: systematic review and meta-analysis of controlled trials. British Medical Journal 323, 773-776.

McClave SA, Sexton LK, Spain DA, Adams JL, Owens NA, Sullins MB, Blandford BS \& Snider HL (1999) Enteral tube feeding in the intensive care unit: factors impeding adequate delivery. Critical Care Medicine 27, 1252-1256.

Marik PE \& Zaloga GP (2001) Early enteral nutrition in acutely ill patients: a systematic review. Critical Care Medicine 29, 2264-2270.

Meakins TS, Persaud C \& Jackson AA (1998) Dietary supplementation with L-methionine impairs the utilization of ureanitrogen and increases 5-L-oxoprolinuria in normal women consuming a low protein diet. Journal of Nutrition 128, 720727.

National Institute for Health and Clinical Excellence (2006) Nutrition Support In Adults. London: NICE.

Peck M, Alexander J, Gonce S \& Maskell P (1989) Low protein diets improve survival from peritonitis in guinea pigs. Annals of Surgery 209, 448-454.

Powell-Tuck J (2007) Nutritional interventions in critical illness. Proceedings of the Nutrition Society 66, 16-24.
Reeds P, Field C \& Jahoor F (1994) Do the differences between the AA composition of acute phase and muscle proteins have a bearing on nitrogen loss in traumatic states? Journal of Nutrition 124, 906-910.

Reeds PJ (2000) Dispensable and indispensable amino acids for humans. Journal of Nutrition 130, 1835S-1840S.

Ruokonen E \& Takala J (2000) Dangers of growth hormone therapy in critically ill patients. Annals of Medicine 32, 317-322.

Shaw J, Wildbore M \& Wolfe R (1987) Whole body protein kinetics in severely septic patients. The response to glucose infusion and total parenteral nutrition. Annals of Surgery 205, 288-294.

Soeters PB, van de Poll MC, van Gemert WG \& Dejong CH (2004) Amino acid adequacy in pathophysiological states. Journal of Nutrition 134, Suppl., 1575S-1582S.

Taylor SJ (2007) Energy and Nitrogen Requirements in Disease States. London: Smith-Gordon and Company Ltd.

Taylor SJ, Fettes SB, Jewkes C \& Nelson RJ (1999) Prospective, randomized, controlled trial to determine the effect of early enhanced enteral nutrition on clinical outcome in mechanically ventilated patients suffering head injury. Critical Care Medicine 27, 2525-2531.

Thompson D (editor) (1996) The Concise Oxford Dictionary, 9th ed. Oxford: Oxford University Press.

Weigle DS, Breen PA, Matthys CC, Callahan HS, Meeuws KE, Burden VR \& Purnell JQ (2005) A high-protein diet induces sustained reductions in appetite, ad libitum caloric intake, and body weight despite compensatory changes in diurnal plasma leptin and ghrelin concentrations. American Journal of Clinical Nutrition 82, 4148.

Wolfe RR, Goodenough RD, Burke JF \& Wolfe MH (1983) Response of protein and urea kinetics in burn patients to different levels of protein intake. Annals of Surgery 197, 163-171. 